\title{
Motor Gelişim Boyutuyla Çocuk ve Spor
}

Hakkı ÇOKNAZ*

\section{Öz}

Beden eğitimi bireyin beden ve ruh sağlığının gelişmesi için yapılan hareketler bütünü iken; spor, bireyin beden ve ruh sağlığının gelişmesi yanında, belli kurallara göre rekabet ölçüleri içinde mücadele etme, yarışma ve üstün gelme amacını içerir. Sporda bedenin yıpranması söz konusudur. Bu nedenle spor yapılırken kişilerin, özellikle de çocukların, yaşa bağlı motor gelişim dönemleri ve hazır olma hali dikkate alınmalıdır. Bu dönemlerde dikkat edilmesi gereken en önemli nokta, çocukların spor dalına özgü hareket evresine kadar çok yönlü, zorlanmadan çalıştırılmalarıdır. Bu çalışmaların içine "müzik" ve "resim" eğitimi de girmelidir. Her spor dalına hitap eden hareket eğitimi niteliğindeki diğer branş çalışmaları, çocuğun spor dalına özgü hareket evresinde seçmesi gerektiği spor branşında başarılı olmasını sağlayacaktır.

Anahtar kelimeler: Motor Gelişim, Çocuk, Spor

\section{SPORTS AND CHILDREN WITH REGARD TO THEIR MOTOR DEVELOPMENT}

\begin{abstract}
While the physical education is the whole of movements done for the development of the physical and mental health of the individual body, sports include the development of the bodily and mental health of the individual, as well as struggle, competition and winning within competitive standards according to certain rules. In sports, body is subject to wear and tear. For this reason, before one is engaged in sports, it is necessary to take into consideration the age, the motor development stages and the state of readiness of the individuals, especially of children. The most important point to note during this period is that children must be trained in a multi-directional manner and without being pressured. These workouts should include "music" and "painting" instructions. Other branch trainings in the form of movement training addressing each sports branch will ensure that the children will be successful in the branch they should choose in the sport-specific movement context.
\end{abstract}

Keywords: Motor Development, Children, Sports

* Doç.Dr., Abant İzzet Baysal Üniversitesi, coknaz_h@ibu.edu.tr 
Spor dünyasında kullanılan kavramlar arasında olan spor, beden eğitimi, egzersiz, antrenman ve hareket eğitimi anlamları dışında kullanılmaktadır. Spor, kişisel veya toplu oyunlar biçiminde yapılan, genellikle yarışmaya yol açan, bazı kurallara göre uygulanan beden hareketlerinin tümü (TDK, 1988) olarak tanımlanır. Beden eğitimi ve spor arasındaki fark kısaca; beden eğitimi, bireyin beden ve ruh sağlığının gelişmesi için yapılan hareketler bütünü iken, sporun ise bireyin beden ve ruh sağlığının gelişmesi yanında, belli kurallara göre rekabet ölçüleri içinde mücadele etme, yarışma ve üstün gelme amacını da içermesidir (Kuter, Kuter, 2012). Antrenman, bir spor branşı için yapılan düzenli bedensel ve ruhsal çalışmalardır. Egzersiz ise birçok alanda olabilir: Piyano egzersizi, matematik egzersizi, beden egzersizi bunlardan bazılarıdır. Egzersiz bir spor branşına yönelik düzenli olmayabilir. Beden eğitimi alanında yapılan "beden egzersizleri" spordan farklıdır. Beden egzersizlerinde yarışma söz konusu değildir, beden performansının sınırları zorlanmayabilir. Hareket eğitimi ise, çocukların motor gelişimlerine yardımcı olacak egzersizlerdir. Hareket eğitimi verilirken çocukların motor gelişim dönemleri dikkate alınmalı ve bilimsel olarak çalışmalar, sporda olduğu gibi, planlanmalıdır.

Motor gelişim dönemleri içerisinde yapılacak hareketlerden lokomotor hareketler, bedenin yüzeyde bulunan sabit bir noktaya göre yer değişikliğini içeren hareketleri (sürünme, emekleme, yürüme, koşma...); manipulatif hareketler bireyin nesne ile ilişkisini gerektiren hareketleri (firlatma, yakalama, vurma...); dengeleme hareketler ise, belli bir derecede denge gerektiren hareketleri (çömelme, dönme, yuvarlanma...) içerir ve çocuklar için basit değildir.

Çocuklarda motor gelişim dönemleri refleks hareketler dönemi (Uterus içi -1 yaş), ilkel hareketler dönemi (0-2 yaş), temel hareketler dönemi (2-7 yaş) ve spor ile ilişkili hareketler dönemi (7-14 yaş ve üstü) şeklinde sınıflandırılmıştır. Refleks hareketler dönemi "bilgi toplama evresi (uterus içi-4ay)" ve "bilgi çözme evresi (4ay-1yaş)"; ilkel hareketler dönemi "reflekslerin ortadan kalktığ evre(0-1 yaş)", "ilk kontrol evresi(1-2 yaş)"; temel hareketler dönemi "başlangı̨ evresi(2-3 yaş)", "ilk evre (4-5 yaş)", "olgunluk evresi(6-7 yaş)"; spor ile ilişkili hareketler dönemi de "genel geçiş evresi (7-10yaş)", "özel hareket becerileri evresi (11-13yaş)" ve "spor dalına özgü hareket evresi (14 yaş ve üzeri)" olarak kendi içlerinde evrelere ayrılmaktadırlar.

Refleks Hareketler Dönemi (Uterus İçi - 1 yaş): Uterus içinde bebek bazı refleks yeteneklere sahiptir. Annenin sesini tanır, dışarıdan gelen uyarılara tepki verir. Annenin, babanın çocukla konuşması, ona şarkı söylemesi, onu okşaması onun ilk egzersizlerinin başlangıcını ve hareket eğitimini içerir. Yani egzersize anne karnında başlanılmaktadır.

Yeni doğanın davranışları daima omurilik ve aşağı beyin merkezlerinden idare edilir. Bebekler bedenlerinin çeşitli bölümlerini hareket ettirmeyi sağlayan genel bir yetenekle ve refleks olarak isimlendirilen davranışsal tepkiler dizisi ile birlikte doğarlar. Bir refleks, bir uyaran türüne özel otomatik bir tepki oluşturur. Örneğin, ışık tutulduğunda göz bebeği otomatik olarak büzülür (Gander ve Gardiner, 1993; Özer ve Özer, 2005).

Aşağı beyin merkezlerinin kontrolündeki ilkel refleksler gebeliğin 18. Haftasından itibaren fötüste görülmeye başlar. Refleksler genellikle yeni doğanın beslenmesini emniyete alma ve 
koruma gibi çift fonksiyonludurlar (Gallahue, 1982; Özer ve Özer, 2005). Refleks hareketleri, tüm fetuslarda ve yeni doğanlarda görülen istem dişı hareketlerdir. Refleksler aracı ile bebek yakın çevresi hakkında bilgi toplar, bedenini tanır. Bu dönemde ortaya çıkan ilkel refleksler (moro, emme, arama, kavrama, plantar, babinski vb.), daha çok beslenme ve korunma işlevi görürken, duruşa ilişkin refleksler (adımlama, emekleme, çekme, paraşüt, propping vb.) daha sonraki istemli davranışlara benzer ve vücudun dik pozisyonunu sağlama işlevini üstlenirler. Refleks hareketler dönemi birbiri ile örtüşen ve birbirini izleyen iki evreden oluşur. Bu evreler bilgi toplama ve bilgi çözme evresidir. Bilgi toplama evresi (uterus içi-4 ay): Bu evre doğum öncesinden başlayarak 4. ayına kadar sürer. Bu evrede refleksler, bebeğin hareketler yolu ile bilgi toplama, besin arama ve korunmasında temel araç olmaktadır(Özer ve Özer, 2005). Bilgi çözme evresi (4 ay-1yaş): Bebeklik döneminde yaklaşık 4. Ayda başlayan bu evrede, beyin merkezlerinin gelişimine bağlı olarak, refleksler giderek yasaklanır. Oturma, emekleme, sıralama, yakalama, bırakma gibi istemli hareketler ortaya çıkar (Gallahue, 1982; Özer ve Özer, 2005). Refleks hareketler dönemindeki bir bebeğin yapmış olduğu tutma, uzanma, sürünme vb. onun ilk manipulatif, lokomotor ve denge hareketlerinden bazılarıdır (Gökmen ve ark., 1995). Bebeğin oyuncaklarla oynaması, ninni dinlemesi, anne/babanın onunla konuşması çocuğun anne karnı dışındaki ilk egzersizleri-hareket eğitimi olarak söylenebilir. Bu egzersizlerden / hareket eğitiminden anne ve baba sorumludur. Anne ve babalar, bu sorumluklarının bilincinde, çocuklarına tüm imkânları sağlamalıdırlar ve onların manipulatif, lokomotor ve denge egzersizlerinden sorumludurlar.

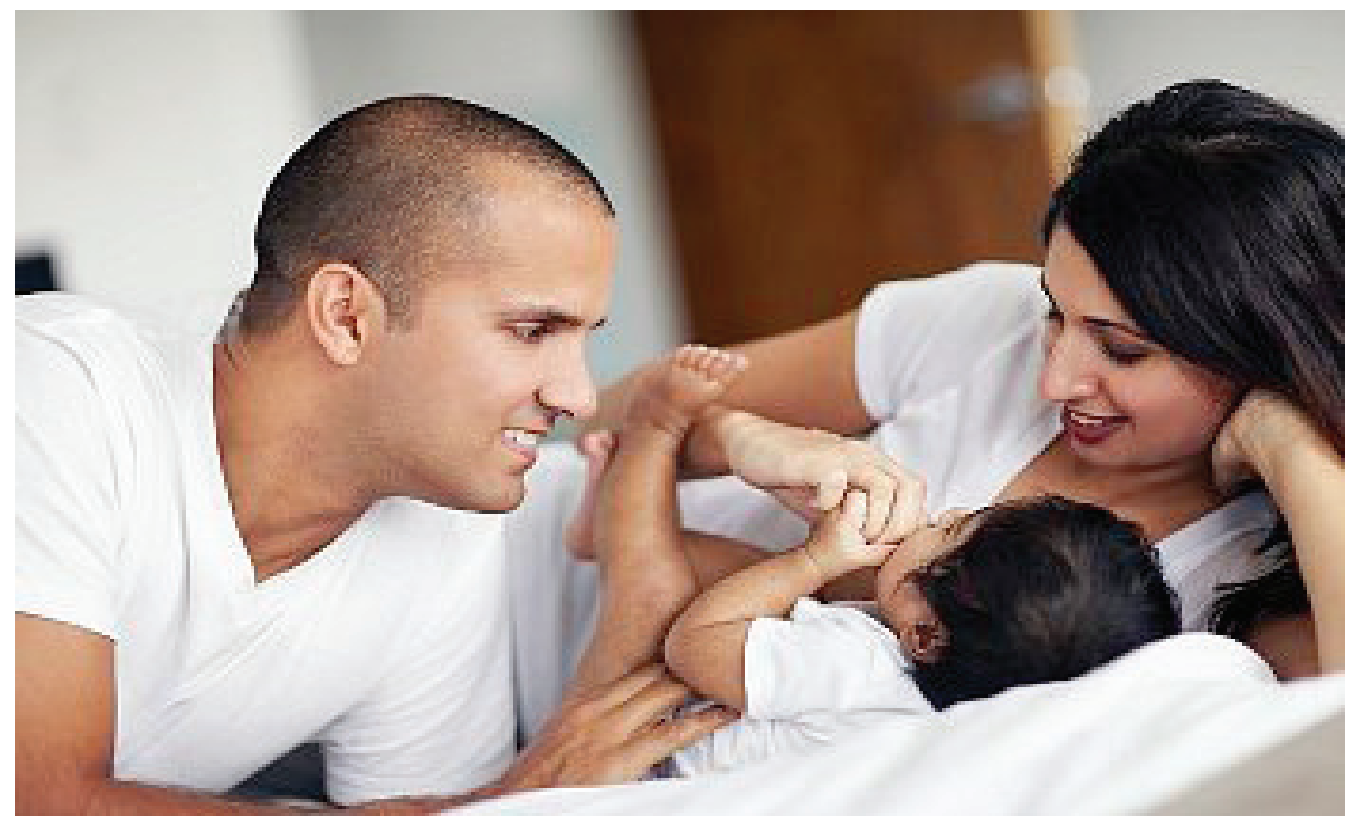


İlkel Hareketler Dönemi (0-2 yaş): İlk istemli hareketlerin ortaya çıktığı doğum ile iki yaş arasını kapsayan dönemdir. İlkel hareketler olgunlaşma ile ortaya çıkan, önceden kestirilebilen bir sıra izleyen hareketlerdir. İlkel hareketlerin ortaya çıkış sırası değişmez iken, ortaya çıkış hızları çocuktan çocuğa, kalıtsal, çevresel ve hareketin özelliklerine bağlı olarak farklılık gösterebilir. Yaşamı sürdürebilmek için gerekli olan ilkel hareketler baş, boyun ve gövde kaslarının kontrolü gibi dengeyi; uzanma, yakalama, bırakmak gibi manipulatif becerileri; sürünme, emekleme, yürüme gibi lokomotor hareketlerini içerir ve iki evrede incelenir. Bu evreler, reflekslerin ortadan kalktığ 1 evre ve ilk kontrol evresidir (Mirzeoğlu ve ark.2003). Reflekslerin ortadan kalktığı evre (0-1 yaş), reflekslerin kaybolduğu, istemli hareketlerin ortaya çıktığı, hareketlerin kontrolsüz, kaba olduğu, hareketlerdeki farklılaşma ve bütünleşmenin zayıf olduğu evredir. İlk kontrol evresi (1-2 yaş) hareketler üzerinde alıştırma yapıldığı, hareketlerde kontrolün sağlandığı, ilkel hareketlerde hızlı kazanım sağlandığı evredir (Mirzeoğlu ve ark. 2003). İlkel hareketler dönemindeki çocuk için sürünme, emekleme vb. onun lokomotor hareketleri iken; uzanma, yakalama, bırakma vb. onun manipulatif hareketlerinden birkaçıdır. Burada da anne ve babalar çocuğun hareket eğitimlerinden sorumludurlar. Çocuklara sağlanacak egzersiz imkânları, onların hareket eğitimlerinin temelini oluşturacağından, çok önemlidir. Çocuklara zarar vermeden evde, veya uygun ortamlarda, anne ve babayla yapılacak egzersizler çocukların gelişimlerini olumlu etkileyecektir. Bu çalışmalar, çocukların ileride seçecekleri spor branşlarının ilk antrenmanlarını oluşturmaktadır.

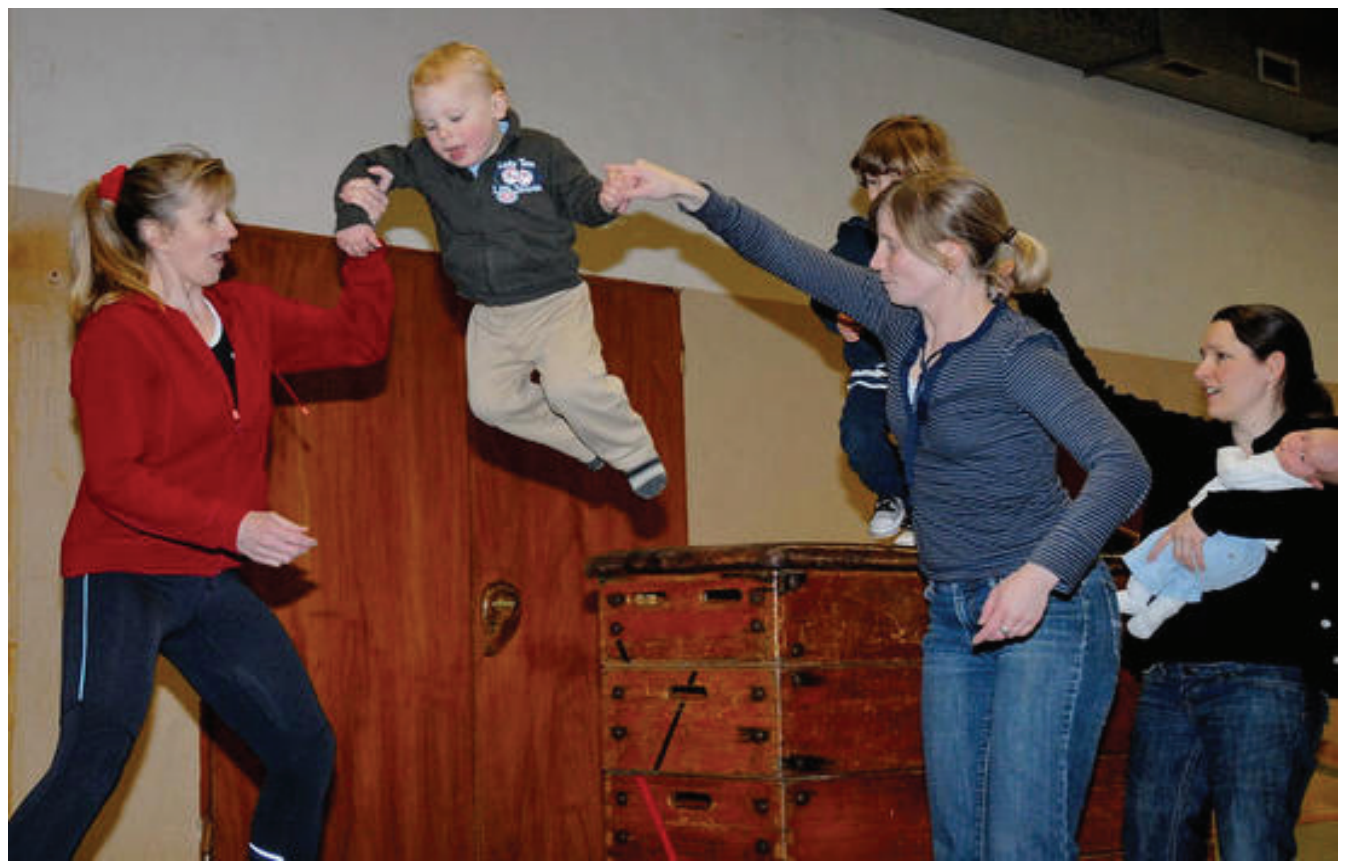


Temel Hareketler Dönemi (3-7 yaş): İlk çocukluk döneminde ortaya çıan ve ilkel hareketlerin uzantısı olan motor gelişimin yoğun olduğu dönemdir. $\mathrm{Bu}$ dönemde, çocuk hareket ederek vücudun hareket potansiyelini keşfeder; beden kısımlarını kullanarak ve aralarında koordinasyon sağlayarak yeni ve daha karmaşık yetenekler kazanır, aktif bir biçimde hareket yeteneklerini araştırarak sınar (Mirzeoğlu ve ark., 2003). Temel hareketler dönemine gelen bir çocuk, ilkel hareketler döneminin becerilerini daha da ileri götürerek, lokomotor hareketler olarak yürümeyi, koşmayı, hoplamayı, sıçramayı, sekmeyi vb.; manipulatif hareketler olarak fırlatmayı, tekmelemeyi, yakalamayı vb.; denge hareketleri olarak denge aleti üzerinde yürümeyi, yuvarlanmayı, takla atmayı vb. gerçekleştirebilmelidir (Gökmen ve ark., 1995).

Temel hareketler döneminde kızlar ve erkekler koşma, atlama, hoplama, firlatma, yakalama, topa ayakla vurma gibi temel hareket yeteneklerinin tümünü geliştirmeye başlarlar. Ne yazık ki birçok eğitimci çocukların bu temel hareket yeteneklerini otomatik olarak öğrendiklerini ve olgunlaşma süreci içinde olgun temel hareket becerilerini geliştireceklerini düşünürler. Çocukların büyük bir çoğunluğu için bu doğru değildir. Olgun temel hareket yeteneklerini geliştirmeleri için çocuklara pratik, destekleme ve öğretim fırsatlarının sunulması son derece önemlidir (Özer ve Özer., 2005). Temel hareketler döneminde çocuk dengeleme, lokomotor ve manipulatif hareketler repertuarını geliştirir, önce bu hareketleri tek tek sonra bir arada nasıl yapıldığını keşfeder (Mirzeoğlu ve ark., 2003). Temel hareketler dönemi, sadece hareketlerin temel özelliklerini içerir, kişisel stil, kişisel özellikleri içermez ve temel hareketlerin kompleks becerileri, örneğin basketbol da şut atma gibi, uygulanması söz konusu değildir. Her hareket modeli önce tek tek incelenir daha sonra kombinasyonlar oluşturulur. Hareket eğitiminde koşma, sıçrama, firlatma, tırmanma, yakalama, tekme atma, çömelme, yuvarlanma, takla atma gibi hareketler birleştirilir (Mirzeoğlu ve ark., 2003).

Temel hareketlerin gelişimi üç evrede incelenir. Bu evreler, gelişimsel bir sıra izlemek ile birlikte her evreyi diğer evrelerden ayırmak mümkün değildir. Başlangıç evresi (2-3 yaş), hareketler sırasında bedenin abartılı veya sınırlı olarak kullanıldığı, ritim ve koordinasyonun zayıf olduğu evredir (Mirzeoğlu ve ark., 2003). Bu evrede çocuklar, kendi bedenlerinin hareket yeteneklerini anlamak ve bunları denemek için çaba gösterirler. Hareket sırasında beden ya çok abartılı ya da çok sınırlı biçimde kullanılır (Özer ve Özer., 2005). İlk evre (4-5 yaş), temel hareketlerde daha fazla kontrolün ve koordinasyonun sağlandığı evre olarak kabul edilmesine rağmen, harekette sınırlılık ve abartının devam ettiği evredir (Mirzeoğlu ve ark., 2003). Üç dört yaş çocukları gözlendiğinde bu evrenin özelliklerini taşıyan pek çok hareket görülebilir (Özer ve Özer, 2005). Temel hareketler döneminin son evresi olan olgunluk evresinde (6-7 yaş), hareket mekanik olarak yeterli, koordineli ve kontrollüdür (Mirzeoğlu ve ark., 2003). Beş - altı yaşına gelen çocukların bu evreye ulaşmış olmaları gerekir (Özer ve Özer, 2005). Bu nedenle, bu yaştaki çocuklar uygun spor salonlarında, uygun araç-gereçlerle egzersizlere ve hareket eğitimlerine başlamalıdırlar; spora değil! Burada, spor salonlarını, çocukların ihtiyaçlarına yönelik tasarımlamak son derece önemlidir. Bazı sporlara bu yaşlarda başlanıldığı bilinmektedir. Bu yaşlarda spora başlayan çocuklarda bedensel ve ruhsal sorunlar, antrenmanların yoğunluğuna bağlı olarak ortaya çıkmaya başlar. Yanlış eğitimli, başarma hırslarından çocukları göremeyen antrenörlerin elinde yetişen sporcu çocukların geleceklerini zayıf sosyal ortamlar da olumsuz etkiler. Bu nedenle, çocuklarla çalışan antrenörlerin bu konuları çok iyi bilmeleri ve kavramaları gerekir. 


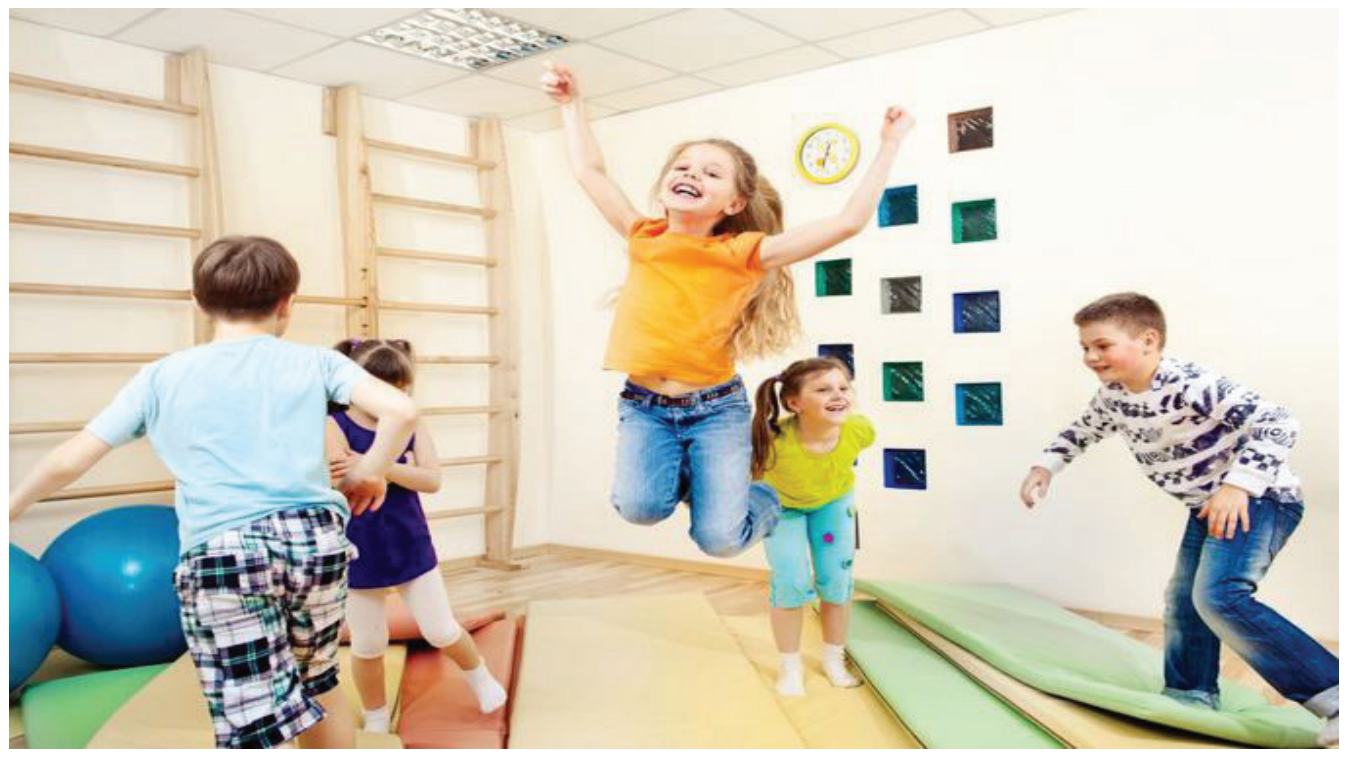

Sporla İlişkili Hareketler Dönemi (7-14 yaş ve üzeri): Motor gelişimin sporla ilişkili hareketler dönemi, temel hareketler döneminin bir uzantısıdır. Bu dönemde hareket birtakım oyunlara, sporlara, danslara ve benzeri aktivitelere uygulanabilen bir araç rolünü alır (Mengütay, 1999). Bu dönemde dengeleme, lokomotor ve manipulatif beceriler giderek mükemmelleştirilir ve birleştirilerek çeşitli etkinliklerde kullanılır. Sporla ilişkili hareketler döneminde becerilerin ne ölçüde, hangi düzeyde gelişeceği çok çeşitli zihinsel, duygusal ve motor etmene bağlıdır. Tepki zamanı, hareket hızı, koordinasyon, vücut yapısı, boy, ağırlık, alışkanlıklar, arkadaş etkisi, duygusal yapı bunlardan bazılarıdır. Sporla ilişkili hareketler dönemi üç evrede incelenir (Mirzeoğlu ve ark., 2003): Genel Geçiş evresi (7-10 yaş): İlk evre geçiş evresidir. Bireyin olgun hareket kalıplarını birleştirme çabalarını gösterdiği bu evrede, birey temel hareket kalıplarını sporla ve rekreatif etkinliklerle ilişkili becerileri gerçekleştirebilmek için birleştirmeye, uygulamaya başlar. Temel hareketler döneminde geliştirilen temel hareketler günlük yaşamda ve çeşitli oyunlarda kullanılır. Bu evrede çocuk tüm spor branşlarına ilgi duyar ve fizyolojik, anatomik veya çevresel faktörlerin kısıtlanmasını hissetmez. Bu evrede çocuk spor becerilerini nasıl perform edeceği hakkında bilgiye sahip olur. Bu hareket becerileri temel hareketlerle aynı öğeleri içerir ama hareketlerde daha fazla biçim, doğruluk ve kontrol vardır. Geçiş evresinde çocuk olgunluk düzeyindeki hareketleri daha karışık ve daha özel biçimlere uygular (Mirzeoğlu ve ark., 2003). Bu evrede öğretmenlerin, annelerin, babaların ve antrenörlerin amacı, çocukların çeşitli aktivitelerde motor kontrol ve hareket yeterliliğini arttırmalarına yardımcı olmaktır. Çocuğun "aktivite içeriğini sınırlandırmak" ve "belli bir branşta uzmanlaşmaya yönlendirmek" doğru değildir (Özer ve Özer, 2005). Özel Hareket Becerileri Evresi (11-13 yaş): Bu evre, sporla ilişkili hareketler döneminin ikinci evresidir. Çocuk bu evrede belirli etkinliklere katılmaya ya da 
onlardan kaçınmaya başlar. Artık performansın biçimi, doğruluğu ve becerili yapımı önem taşır (Mirzeoğlu ve ark., 2003). Bu dönemde çocuk “isterse” bir "spor branşına” yönelebilir, ama yaptığı çalışmaların "çok yönlülüğünü” kaybetmemelidir (Muratl1,1992). Çocuğun beceri gelişiminde 11'den 13 yaşa kadar ilginç değişimler yer alır. Çocuk bu dönemde fiziksel kapasitenin ve sınırlılıklarının farkına varmaya başlar. Artan zihinsel yetenekler ve deneyimlerle, çeşitli etmenleri de dikkate alarak tüm spor branşlarında belli bir branşa odaklaşmaya başlar. Bir başka deyişle, çocuk hoşlandıkları ve hoşlanmadıkları, güçlü ve zayıf yönleri, olanaklar ve olanaksızlıklara dayalı olarak etkinlik alanını sınırlandırma konusunda bilinçli kararlar vermelidir (Özer ve Özer, 2005). Bu kararların verilmesinde bilinçli antrenörlerin yardımına ihtiyaç vardır. Bilinçli, iyi eğitilmiş, çocuk pedagojisinden anlayan antrenörler velilere çocuklarının hangi spor branşında başarılı olabileceklerini bilimsel olarak anlatmalıdırlar. Çocukların yaşamlarında mutlu olabilmeleri için seçtikleri branşlarda da mutlu olmaları gerekir; seçtikleri branşlarda mutlu olabilmeleri için de o branşta başarılı olmaları gerekir; bunun için de doğru branşlarda spora başlamalıdırlar. Böylece spordan zevk alan, mutlu sporcu çocuklar ortaya çıkabilir. Spor Dalına Özgü Hareket Evresi (14 yaş ve yukarısı): 14 yaşında başlayan ve yaşam boyu devam eden bu evrenin en önemli özelliği bireyin kazanmış olduğu hareket becerilerini yaşam boyu kullanmasıdır. Bir önceki evrede yapılan seçimler ilgi ve yeterlilikler mükemmelleştirilir, günlük yaşama, rekreasyona ve sporla ilişkili aktivitelere uygulanır. Bu evre, daha önceki dönem ve evrelerin zirvesini oluşturur (Gallahue ve Ozmun, 1998; Özer ve Özer, 2005). Bu dönemin en önemli özelliği, bireyin kazanmış olduğu hareket becerilerini yaşam boyu ve sporda kullanmasıdır. Bir önceki evrede belirlenen ilgiler, yetenekler ve seçimler bu evreye taşınır ve bu evrede daha da sınırlandırılır. Zaman, para, tesis, malzeme vb. etmenler bu evredeki kalıtımı etkiler. Etkinliğe katılım düzeyi bireyin yeteneklerine, olanaklara, fiziksel özelliklere, motivasyona ve geçmiş deneyimlere bağlı olarak değişir (Özer ve Özer, 2005). Performans düzeyi rekreatif etkinliklere katılmadan profesyonelliğe kadar uzanan doğrunun herhangi bir noktasında olabilir. Performans otomatik gibi görünür ve güvenilirdir. Bu evre, kendinden önceki dönem ve evrelerin bir birikimidir ve yaşam boyu devam eden süreç olarak görülmelidir (Mirzeoğlu ve ark., 2003). “Çocuk bu dönemde artık sporcu olmuştur.” Sporcu olan çocuklara doğru antrenman programları uygulandığında gelişimleri mükemmel olacaktır. Ne yazık ki, bu dönemde bilinçsiz antrenörlerin elinde fiziksel ve psikolojik çöküntü yaşayan sporcu çocukların gelecekteki kişilikleri de çöküntü içinde olacaktır. 


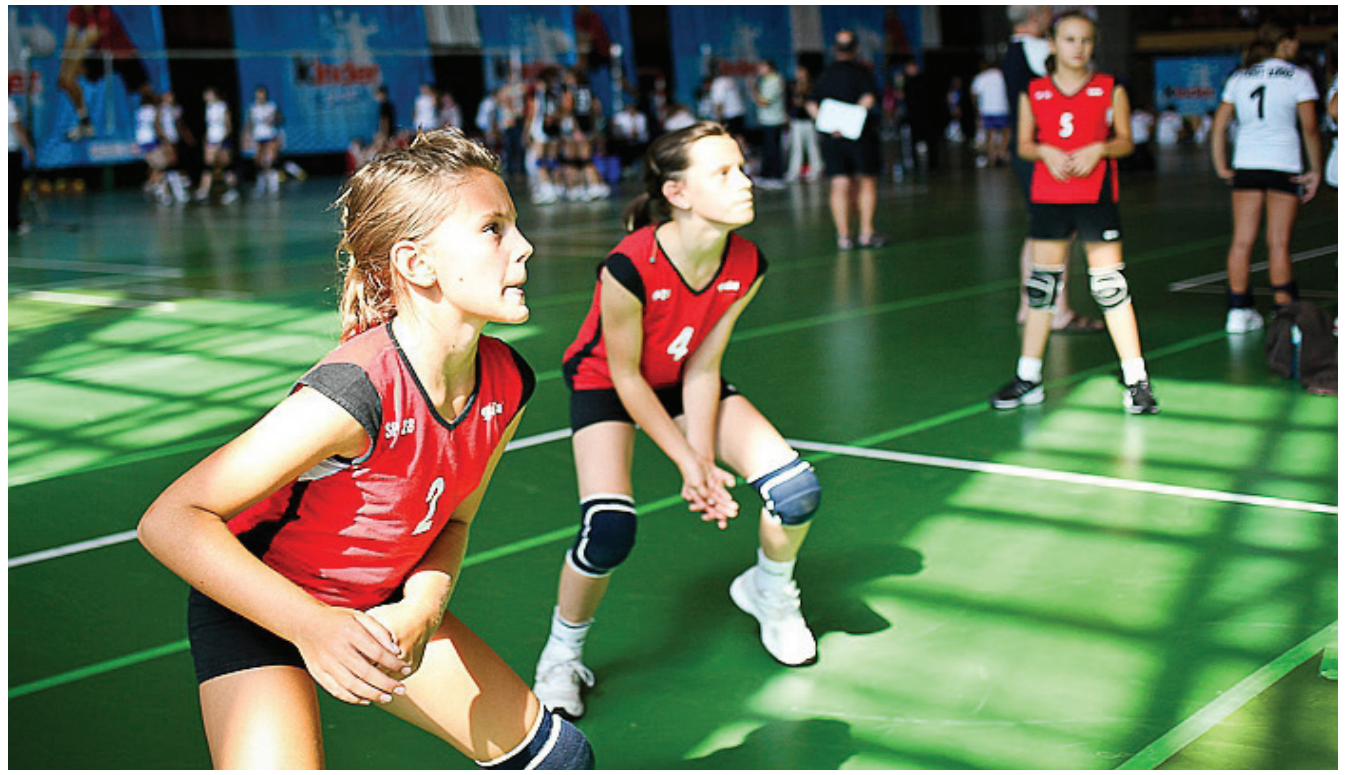

Yukarıda bahsettiğim dönemlerde dikkat edilmesi gereken en önemli nokta, çocukların spor dalına özgü hareket evresine kadar çok yönlü, zorlanmadan çalıştırılmalarıdır. Bu çalışmaların içine "müzik" ve "resim" eğitimi de girmelidir. Her spor dalına hitap eden hareket eğitimi niteliğindeki diğer branş çalışmaları, çocuğun spor dalına özgü hareket evresinde seçmesi gerektiği spor branşında başarılı olmasını sağlayacaktır. Bizlerin hatası, beş-altı yaşındaki kız ve erkek çocuklarını ağlatarak esneterek, onlara egzersiz yaptırdığımızı sanmamız ve çocukların çok yönlü bedensel ve ruhsal gelişimlerini engellememizdir.

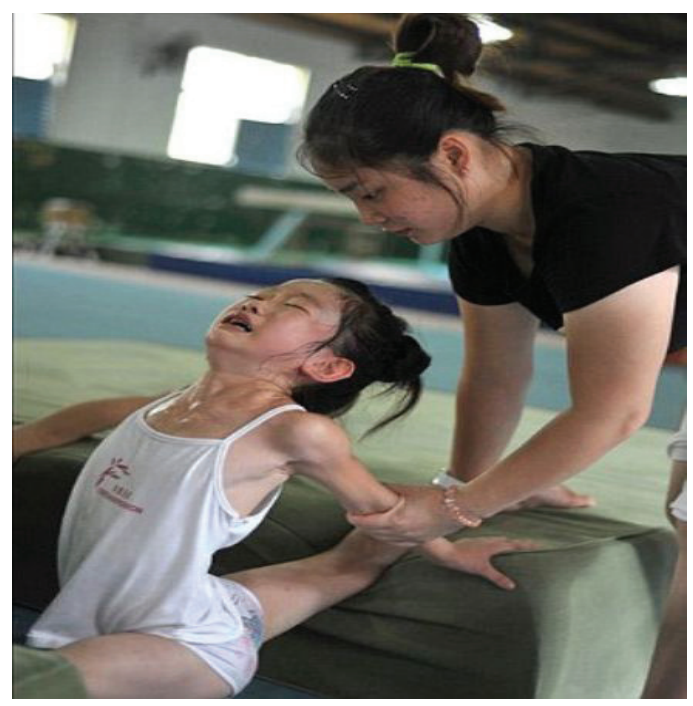




\section{KAYNAKLAR}

Gallahue D. (1982). Understanding Motor Devolopment in Children, Jhon Wiley\&Sons, New York

Gallahue D. and Ozmun J. C. (1998). Understanding Motor Development: Infants, Children, Adolecents, Adults, Mc. GrawHill

Gander J. M., Gardiner W. H. (1993). Çocuk ve Ergen Gelişimi I, Çev: Onur B. (Ed.) İmge Kitabevi, Ankara Gökmen H. ve Ark., (1995). Psikomotor Gelişim, G.S.G.M., Yayın No:139, Ankara

Kuter F. Ö., Kuter M. (2012). Beden Eğitimi ve Spor Yoluyla Değerler Eğitimi, Eğitim ve İnsani Bilimler Dergisi: Teori ve Uygulama, Cilt: 3, Sayı: 6, 75-94

Mengütay S., (1999). Okul Öncesi ve İlkokullarda Hareket Gelişimi ve Spor, Tutibay Yayınları, Ankara

Mirzeoğlu N. ve Ark., (2003), Spor Bilimlerine Giriş, Bağırgan Yayınevi, Ankara

Muratlı S. (1992). Çocuk ve Spor, Bağırgan Yayımevi, Ankara

Özer D.S., Özer K. (2005). Çocuklarda Motor Gelişim, Nobel Yayın Dağıtım, Ankara

T.D.K. (1988). Türkçe Sözlük, Türk Tarih Kurumu Basımevi, Ankara 
